\title{
Measuring Life Insurance Service Quality: An Empirical Assessment of SERVQUAL Instrument
}

\author{
Ms. Neetu Bala (Corresponding Author) \\ Assistant Professor, Maharaja Agrasen College \\ University of Delhi, Vasundra Enclave, Delhi -110096, India \\ E-mail: neetucancerion@gmail.com \\ Dr. H.S Sandhu \\ Director, SAI Technology Campus, Amritsar, Punjab, India \\ E-mail: sandhu_hs12@yahoo.com
}

Dr. Naresh Nagpal

Excecutive Director, Shri SAI Group of Institutes, Chandigarh, India

E-mail: ed@srisaigroup.in

Received: August 12, 2011

Accepted: August 29, 2011

doi:10.5539/ibr.v4n4p176

\begin{abstract}
With the entry of so many players in the field and the consequent competitive activism, the entire gamut of the service sector is witnessing a multi-dimensional, purposeful, consumer-friendly approach, shedding off the lethargy that had come to be associated with the sector. One of the leading insurance companies of the service sector, Life Insurance Corporation (LIC) of India has experienced an equally profound impact of competition. One of the greatest challenges forcing the life insurance player is to differentiate its services through quality improvement. The aim of paper is to test the reliability and to examine the dimensionality of SERVQUAL instrument in the life insurance sector. Besides, the study has identified deficiencies in the specific areas of service quality where concentrated efforts are required to be made. Data has been collected from 337 customers from three cities of Punjab to know their perceptions and expectations level at seven point Likert scale towards service quality of LIC. The findings of the study indicate that the gap scores do not merge into five dimensions of service quality; rather, the perception scores merge into three dimensions. Evidently, SERVQUAL instrument cannot be applicable to the Indian life insurance sector and further research is necessitated to comprehend the service quality within the Indian context.
\end{abstract}

Keywords: Service quality, Life insurance, SERVQUAL, Dimensionality

\section{Introduction}

Quality is one of the competitive priorities which have migrated from the literature of manufacturing strategy to the service arena (Pariseau and McDaniel, 1997). In the service sector, the quality of service, one of the most dominant themes of research in services, has become a strategic instrument for firms since 1990s (Fisk et al., 1993; Donnelly et al., 1995). Customer perceives services in terms of its quality and how satisfied they are overall with their experiences (Zeithaml, 2000). According to Timmers and Van Der Wiele (1990), satisfying the customer is not enough: there is a compelling need to delight the customer if a competitive advantage is to be achieved. The key to sustainable competitive advantage in today's competitive environment lies in delivering high-quality service that result in satisfied customers (Shemwell et al., 1998). In fact, service quality has become a great differentiator, the most powerful competitive weapon which many leading service organizations possess (Berry et al., 1985).

Service sector has produced approximately two-thirds of worldwide GNP from twenty first century (Kara et al., 2005). In the huge service sector, insurance sector is one of the most important entities which has been growing relatively fast in India. In a period of half century or less, the insurance sector in the country has undergone roundabout movement, from being an open competitive market to full nationalization, and then back again to a liberalized market, in which private players and public sector companies are operating on a level playing field. At present there are twenty three players in the Indian life insurance industry out of which Life Insurance Corporation (LIC) is one of the leading public companies, holds largest number of policies in the world to suit different financial requirement of an individual. LIC stands for trust and is servicing 270 million policyholders in India and abroad (www.licindia.in). 
With a greater choice and an increasing awareness, there is a continuous increase in the customers' expectations and they demand better quality service. As a result, LIC and private players are competing with each other in each and every aspect of their functioning i.e. from product designing to the settlement of claims and ensuring benefits to the Indian customers. Sherden (1987) laments that high quality service (defined as exceeding "customers' expectations") is rare in the life insurance industry but increasingly demanded by customers. According to Siddiqui et al. (2010) in the life insurance sector, most of the companies have equivalent offerings and establishing better service quality may be the only way of differentiating itself from the others. Such differentiation can yield a higher proportion of consumers' choices, and hence mean the difference between financial success and failure.

In spite of the growing importance of service quality (Qualls and Rosa, 1995), it remains an abstract and elusive construct that is difficult to define and measure (Carman, 1990; Crosby, 1979; Gravin, 1983; Parasuraman et al., 1985, 1988; Rathmell, 1966). In the empirical literature, there are many alternative service quality models and instruments developed for measuring service quality. SERVQUAL instrument developed by Parasuraman et al. (1988) is one of the most pre-eminent and widely used instruments for measuring the service quality as perceived by the customers. Numerous scholars (Ovretveit, 1993; Yang, 2003; Sinclair and Zairi, 1995; Silvestro et al., 1990) have emphasized the importance of service quality measurement, as it judges not only the external perceptions but also the real effectiveness of an organization operation. As a matter of fact, the invaluability of service quality as a marketing force in the ever-growing competition in the life insurance sector can never be overemphasized. Although, service quality is found rich in empirical studies on different service sectors hardly any study has yet been conducted to assess the dimensionality of SERVQUAL instrument in the life insurance sector from the Indian context. Hence, to make up for this lack, the present study is conducted to test the reliability and to examine the dimensionality of SERVQUAL instrument in order to better approach this instrument to measure service quality of LIC of India. Furthermore, using data from customers, specific areas have been identified in which quality improvement is an essential requisite. Consequently, quality improvement strategies have been recommended for LIC to improve its services productively.

\section{Literature Review}

Parasuraman et al. (1985) revealed ten dimensions viz., tangibles, reliability, responsiveness, competence, courtesy, credibility, security, communication, understanding, and access in the original model of service quality. But in the subsequent study of Parasuraman et al. (1988), these ten dimensions were condensed into five viz., tangibles, reliability, responsiveness, assurance, and empathy. This led to the development of a 22-item SERVQUAL scale for measuring service quality. According to the SERVQUAL scale, service quality can be measured by identifying the gaps between customers' expectations of the service to be rendered and their perceptions of the actual performance of the service. It is the most frequently used model to measure service quality (Mattson, 1994) and made to be used by services organizations or industries to improve service quality (Parasuraman et al., 1988). Obviously, the SERVQUAL instrument has been used to measure service quality in various service industries which included health sector (Babakus and Boller, 1992; Carman, 1990; Bowers et al., 1994; Headley and Miller, 1993; Lam, 1997; Kilbourne et al., 2004); retailing (Teas, 1993; Finn and Lamb, 1991; Tsai and Huang, 2002; Naik et al., 2010); banking (Lam, 2002; Zhou et al., 2002); hospitality (Mey et al., 2006; Spreng and Singh, 1993); sports (Kouthouris and Alexandris, 2005); telecommunications (Van Der Wal et al., 2002); and information system (Jiang et al., 2002; Carr, 2002). In addition, there have been several contextual studies (Stafford et al., 1998; Leste and Vittorio, 1997; Westbrook and Peterson, 1998; Mehta et al., 2002; Evangelos et al., 2004; Goswami, 2007; Gayathri et al., 2005; Siddiqui et al., 2010) regarding the insurance industry.

Additionally, a review of the relevant literature also reveals that the principal focus of service quality research has been twofold: First, the identification of service quality dimensions being of primary interest to researchers (Parasuraman et al., 1985,1988, 1991b); and second, the development of measurement instruments of service quality being the focus of subsequent research efforts (Parasuraman et al., 1988, 1991a, 1993; Cronin and Taylor, 1992, 1994; Asubonteng et al., 1996, Buttle, 1996). Numerous researchers have confirmed the applicability of five dimension model in different sectors in different countries (e.g. Gabbie and Neill, 1996; Bojanić and Rosen, 1994; Mehta and Durvasula, 1998; Lam and Zhang, 1999); however in some studies the five dimension model was not confirmed (e.g. Carman, 1990; Babakus and Boller, 1992; Brown et al., 1993; Ryan and Cliff, 1996; Zhao et al., 2002; Wang et al., 2004; Jain and Gupta, 2004; Evangelos et al., 2004). In the various other significant studies, the SERVQUAL scale has been presented in different dimensions - single-dimensional (Babakus et al., 1993; Lam, 1997), two-dimensional (Babakus and Boller, 1992; Nadiri and Hussain, 2005; Karatepe and Avci, 2002; Ekinci et al., 2003; Evangelos et al., 2004), three-dimensional (Mei et al., 1999), four-dimensional (Gagliano and Hathcote, 1994; Kilbourne et al., 2004), six-dimensional (Headley and Miller, 1993), seven-dimensional (Freeman and Dart, 1993), nine-dimensional (Carman, 1990), and nineteen-dimensional (Robinson and Pidd, 1998) construct. Besides, a number of researchers in different contexts have reported different dimensions for expectations, perceptions, and gap scores (Arasli et al., 2005; Zhao et al., 2002; Parikh, 2006). In summing up, Babakus and Boller (1992) commented that "the domain of service quality may be factorially complex in some industries and very simple and uni-dimensional in others". In effect, authors claim that the number of service quality dimensions is dependent on the particular service being offered. 
Dotchin and Oakland (1994) states that dimensionality of SERVQUAL depends on the context in which it is applied and cannot be generalized in all and any service industry. Similarly, Brown et al. (1993) suggested that SERVQUAL has to be modified and adapt-based on the industry, the business and the location. Ozer (1999) recommends the development of industry-specific quality measurements for a better fit to the nature of the industry. As a result, numerous studies in different service sectors have sought to develop industry-specific service-quality scales. For example, several scales have been replicated, adapted and developed to measure services by taking SERVQUAL as a base, viz., SERVPERF (Cronin and Taylor, 1992, 1994) for hotels, clubs and travel agencies; DINESERV (Stevens et al., 1995) for food and beverage establishments; LODGSERV (Knutson et al., 1990) for hotels; SERVPERVAL (Petrick, 2002) for airlines; SITEQUAL (Yoo and Donthu, 2001) for Internet shopping; E-S-QUAL (Parasuraman et al., 2005) for electronic services; SELEB (Toncar et al., 2006) for educational services; HISTOQUAL (Frochot and Hughes, 2000) for historic houses; LibQUAL (Cook et al., 2002) for library ; and ECOSERV (Khan, 2003) for ecotourism.

Since SERVQUAL was developed in a Western country, it has been suggested that researchers should be sensitive to cultural differences in examining the dimensionality of service quality in other countries (Kettinger et al., 1994). In an examination of cross-cultural differences between North American and Latin American consumers, Espinoza (1999) found that the relative importance of service quality dimensions was different between the two groups. Moreover, the SERVQUAL instrument has been criticized for its lack of applicability in service industries in developing countries (Jain and Gupta, 2004) and its inconsistent perception and expectation scores in cross-cultural studies (Zhao et al., 2002). Furrer et al. (2000) claims that customers from different cultures perceive service quality differently. Voss et al. (2004) partly support this claim; they found that UK and USA customers have different reactions to poor service.

The review of literature reveals that SERVQUAL, designed to be a generic instrument applicable across a broad spectrum of services, has been extensively used, replicated, and found inadequate in many cases, however has not been perspectively applied in the Indian life insurance sector. As a consequence, it was decided to use the SERVQUAL instrument to measure the level of services provided by LIC and to find out its suitability in the Indian life insurance sector.

\section{Research Methodology}

The study was conducted on LIC customers located in the major cities, namely, Amritsar, Jalandhar, and Ludhiana of Punjab, a progressive state of India. For choosing the sample, non-probabilistic convenience sampling technique was used. A sample of 450 customers was taken up who were approached personally at their work places. Out of the total, 337 responses (75 percent) were found to be valid and used for the purpose of analysis.

SERVQUAL - 22 item scales as proposed by Parasuraman et al. (1988) has been employed for collecting data regarding the customers' perceptions and expectations of various service attributes. The discrepancy between perception and expectation (termed the P-E or gap) is a measure of service quality. Questionnaire consists of two scales, titled perceptions and expectations. The perceptions scale is a set of 22 items encompassing the five dimensions that describe what the customers actually think of the service. The expectations scale is a set of 22 matching items that describe what customers expect from an excellent company. Respondents were asked to indicate their perceptions and expectations level for each of the 22 items in the questionnaire using a seven-point Likert scale (ranging from 1 indicating 'very strongly disagree' to 7 indicating 'very strongly agree'). The instrument was pre-tested on 150 customers from Amritsar city. This consequently led to some modifications in the SERVQUAL items. Two items under reliability, three items under empathy, two items under responsiveness, and two items under tangible dimensions, were clubbed into one item each to make the questionnaire more recognizable by the surveyed respondents. Further, one item of SERVQUAL instrument, viz., error free record was confusing; hence it was eliminated from the final questionnaire. The detail of the SERVQUAL instrument and the corresponding modified items used in the current study is presented in Appendix I.

Moreover, the negative wording in the SERVQUAL instrument caused serious problems in terms of reliability and practical interpretation of the data collected (Zhao et al., 2002), and thus, was avoided in the present study. The revised instrument consisting of 16 items was then used for the main data collection. Various statistical tests, viz., reliability analysis, weighted average scores, and factor analysis have been carried out. This study has used SPSS 11.5 software package to analyze the data.

\section{Data Analysis and Results}

\subsection{Sample Characteristics}

The demographic profile of sampled customers is furnished in Table 1. The sample consists of a sizeable preponderance $(72.1 \%)$ of male respondents over female $(27.9 \%)$ respondents. The respondents are mostly spread between the ages of 21 to $40(57.3 \%)$ and 41 to $60(38.6 \%)$. In terms of marital status, a significant majority of the respondents $(82.5 \%)$ are married while $17.5 \%$ of the respondents are unmarried. Majority $(94.4 \%)$ of the respondents belong to urban areas whereas only 5.6\% reside in rural areas. Most of the surveyed respondents $(43.3 \%)$ are from 
Amritsar, followed by Jalandhar (33.8\%) and Ludhiana (22.9\%). In terms of academic qualifications, it is not surprising that majority (39.8\%) of the respondents is graduate followed by post graduates $(32.3 \%)$, professionals $(19.3 \%)$, senior secondary pass $(6.5 \%)$, and matriculates $(1.2 \%)$. As regards the occupation of the respondents, close to half $(43 \%)$ are in service class, while $11.5 \%$ are businessmen, and $19.3 \%$ are professionals.

Table 1 also indicates that as high as $46.3 \%$ of the respondents fall in the income range of Rs. 15001 to 30000 and as low as $15.7 \%$ are getting about Rs. 45000 . In general, the majority (40.7\%) of respondents has bought only one policy, while $30.6 \%$ have more than two policies of LIC. As regards the mode of premium payment, the majority (46.3\%) of respondents prefers to make yearly payment, $23.1 \%$ prefer half yearly, followed by $17.5 \%$ quarterly, and $7.1 \%$ monthly respectively. $5.9 \%$ respondents make the most of premium payments for different policies through more than two modes.

\subsection{Reliability Analysis}

In order to test the reliability of the SERVQUAL scale and the internal consistency of the five dimensions as suggested by Parasuraman et al. (1988), Cronbach's coefficient alpha was computed for each of the five dimensions using data on perceptions, expectations, and gap (the differences between the perceptions and expectations) scores. The reliability coefficients for the life insurance customers are shown in Table 2 . The results show that the internal consistency of the perceptions (P) scale in all dimensions is all quite higher than the gap (P-E) scale. All the five dimensions have internal consistency measures equal to or more than the cutoff value of 0.70 suggested in the literature (e.g. Nunnally and Bernstein, 1994; Hair et al., 2010), therefore, perception scale demonstrated high reliability. This indicates that the customers showed a better understanding of the questions, which resulted in the higher consistency of the answers. However, the reliability coefficients for the expectations (E) scores were much lower. All the five dimensions of expectations scores and empathy dimension of gap scores measured reliability coefficients of below 0.60 , which is the minimum satisfactory value (Malhotra, 2007), even for exploratory research (Zhao et al., 2002). This indicates that customers have failed to understand rightly the questions related to these dimensions.

Overall reliability of the perception (0.9110), expectations (0.7842), and gap (0.8701) scales were also quite high and hence deemed acceptable (Nunnally and Bernstein, 1994; Hair et al., 2010). By and large, the results in Table 2 do indicate that there are few reliability problems in using the gap model to measure service quality.

\subsection{Factor Analysis}

In order to examine the dimensionality of SERVQUAL instrument from the Indian perspective, an exploratory factor analysis using the principal component method with varimax rotation on the perceptions, expectations, and the gap scores for the customers was performed. The test was performed separately on perceptions, expectations, and gap scores for checking the applicability of gap analysis for the factor structure as proposed by Parasuraman et al. (1988). Only few studies (Parikh, 2006; Zhao et al., 2002; Zhou et al., 2002) had applied an exploratory factor analysis separately on the perceptions, expectations and the gap scores to assess the dimensionality of SERVQUAL instrument. The results of such analysis for the perceptions, expectations, and the gap scores are shown in Tables $3,4 \& 5$ respectively. Importantly, before conducting the exploratory factor analysis, the adequacy or appropriateness of data for factor analysis was examined with the help of Kaiser-Meyer-Oklin (KMO) Measure of Sampling Adequacy (MSA) and Bartlett's test of sphericity. In this study, value of KMO was excellent because it exceeded the recommended value of 0.6 as suggested by Hair et al. (2010). Moreover, the Bartlett's Test of Spehericity was also significant $(0.000)$ (see Table $3,4,5)$. The results thus indicated that the sample taken was appropriate to proceed with a factor analysis procedure.

Further, for defining the factors clearly, two criteria have been employed. First, it was decided to delete any variable which did not load at least $( \pm)$ 0.50. Second, it was decided that a factor must be defined by at least two variables. This criterion is consonant with the observations made by Rahtz et al. (1988). With this criterion in mind, a series of factor analysis was performed on the data. Following each analysis, items which did not meet the criteria, were deleted from the analysis. Table 3, $4 \& 5$ explain the extracted factors along with the loadings for all items, eigen values, Cronbach alpha, and the percentage of variance explained by each factor.

The exploratory factor analysis of perception scores results in Table 3 indicate that the 16 items do not support the five-factor structure as proposed by Parasuraman et al. (1988) and yield a three-factor solution. Furthermore, the factors do not load according to the factor structure given by Parasuraman et al. (1988). For example, some of the items on assurance, empathy, and responsiveness come together under F1. Besides, all tangibles items properly loaded to a single factor together with third item of empathy under F2. It indicates item E3 primarily loads to the tangibles dimension rather than to its original dimension of empathy. Another item that showed a problem with loading on one factor was the third item under 'reliability' (RL3), which had an almost equal loading for F1 and F3. To improve the factor loading that item was deleted from the analysis. 
Meanwhile, three-factor solution explaining $65 \%$ cumulative variance, which is higher than $50 \%$ as recommended by Nunnally and Bernstein (1994). F1 explains maximum variance (44.3\%) followed by F2: $11.7 \%$ and F3: $8.8 \%$ variance, respectively. It means that factor analysis has extracted a good amount of variance in the items. Eigen values range from 1.314 to 6.639 . The coefficient alpha values of all the three factors $(0.9094,0.8332$, and 0.7473$)$ are well above the recommended rule-of-thumb.

The factor loading of five dimensions were even more problematic in case of expectation scores. In addition, all items were not found loaded according to the proposed factor structure of Parasuraman et al. (1988). From Table 4, it is revealed that the expectations scores are distributed among four distinct factors. All the three items (A1, A2, A3) of assurance factor are divided into two new factors where A1 and A2 (under F1) stand for the customer perception as to whether agents/employees have the proper knowledge and competence to answer customers' specific queries \& requests; and instill confidence in customers by proper behavior, respectively. A3 (under F3) are concerned with whether the agents/employees are making customers feel safe and secure in their transactions. Even though, two items of tangibles (T2, T3) are loaded to a single factor (F4) whereas T1 is loaded under F2 along with third item of empathy. Moreover, F1 shows a combination of empathy, reliability, assurance, and responsiveness items. All items were found highly loaded under four distinct factors barring third item of 'reliability' (RL3). It indicates customers are highly dissatisfied with this statement. Resultantly, LIC has to make effective improvements in respect of "showing sincere interest in solving customers' problems".

Overall result of Table 4 does not support the five-dimension structure of service quality as suggested by Parasuraman et al. (1988). In addition, the four factors so generated have eigen values between 1.139 to 4.027 and explaining $58.6 \%$ cumulative variance. F1 explains $25.2 \%$ variance followed by F2: $11.0 \%$, F3: 8.8\%, and F4: 7.1\%. Reliability of first two factors $(0.7569,0.7136,0.5127$, and 0.4884$)$ was all quite high according to coefficient alpha. The lack of reliability in F3 and F4 might be due to the misunderstanding of the questions related to these dimensions.

The exploratory factor analysis on gap scores (P-E) result in Table 5 indicates that the 16 items do not match the five-factor structure as developed by Parasuraman et al. (1988). Overall, the analysis of gap scores gave three-factor solution instead of five-factor. Even within these factors, the items were not found loaded according to the proposed factor structure of Parasuraman et al. (1988). For example, the third question on assurance (A3) does not load on the same factor as the other three questions on assurance. In addition, the responsiveness, empathy, and assurance items merged into a single factor i.e. F1, while the three reliability items formed a new factor (F3) together with one assurance item. Above and beyond, all items on tangibles are properly loaded together with one empathy item under F2. This dimension seeks customers' agreement on the visually appealing material \& facilities, neat \& professional appearance of staff, and modern looking equipment, rightly. All items were found highly loaded on this dimension. Table 5 evidently indicates that some items did not load to any factor while other items merged into a single factor. Apparently, this result does not support the five-factor structure as proposed by Parasuraman et al. (1988). It is worth mentioning here that the findings are in conformity with Evangelos et al. (2004) who employed factor analysis to examine the dimensionality of gap scale and found two-factor solution viz., non-tangibles (consisting four factors viz., reliability, responsiveness, empathy, assurance) and tangibles (consisting tangible items) instead of five-factor as proposed by Parasuraman et al. (1988) to measure service quality in Greece insurance industry.

Table 5 depicts, SERVQUAL ultimately resulted in three factors explaining 55\% cumulative variance and showing eigen values between 1.258 to 5.752. F1 explains maximum variance (35.9\%) followed by F2: $11.0 \%$ and F3: $7.9 \%$ respectively. The Cronbach's alpha value for all the three factors lay between 0.8696 and 0.6864 . F2 and F3 are showing reliability near to the cut-off value of 0.70 . Finally, overall results of exploratory factor analysis presented in Tables 3, 4 \& 5 highlight that the factors obtained under perceptions, expectations, and gap scores do not match the five-factor structure of service quality. In fact, these results indicate potential problems in using the gap model to measure service quality at the factor level using the same factor structure as proposed by Parasuraman et al. (1988).

\subsection{Gap Analysis and Identification of Areas for Improvement}

Although factor analysis results of gap scores did not support the five-factor structure of service quality as proposed by Parasuraman et al. (1988), yet Evangelos et al. (2004) asserted that the five quality dimensions of SERVQUAL would better identify specific areas for which quality improvement is necessary. Hence, in the present study instead of dimension level (due to the inapplicability of the same factor structure) the gap scores for individual items were analyzed using the Weighted Average Scores (WAS) for all the 16 items to identify areas where quality improvement by LIC is needed the most.

As expected (Parasuraman et al., 1985, 1988), the results (shown in Table 6) revealed that in all the attributes of service quality of LIC, the gap scores are negative. Levy and Weitz (2005) posit that customers are satisfied when the perceived service meets or exceeds their expectations. They are dissatisfied when they feel the service falls below their expectations. From Table 6, it is clear that negative gaps were found in all 16 items indicating that customers' expectations were in excess of their perceptions. In other words, service quality of LIC at an overall level falls far below the customer expectations. This can be interpreted as a gap between what was expected and perceived, thus, 
representing a failure in service delivery and service quality at all the levels. By analyzing the 'gaps', insurer has the opportunity to take the appropriate actions to improve the quality of their services, giving priority to items with the largest gap scores.

Table 6 indicate that the maximum gap (-2.15) among all the items was found to be in item 15 in the area of being neat and professional. The next high gap (-2.02) existed in item 14 in the area of visually appealing materials and facilities. The third substantial gap (-1.97) existed in item 16 in the area of modern equipment, fixtures \& facilities. The higher negative scores indicate that those attributes may not be available or at the most be inadequate to users even if available. Besides, biggest gaps call for the need for immediate attention by service provider to make improvements in these areas.

The lowest gap (-1.51) was found to be in item 3 which shows that agents fail to make customers feel safe and secure in their transactions. The attributes with lowest negative value can, however, in no way be ignored by service provider. Therefore, in order to reduce the gap, LIC must have to provide excellent training, education \& awareness to its staff to provide excellent services to the customers by building a relationship of trust. Eventually the lack of proper factor structure as revealed by the analysis of data, the weighted average scores of the items of gap scale points out to the need for considerable improvements in the LIC service quality in all aspects.

\section{Discussion and Managerial Implications}

The results show that most of the items proposed under five dimensions by Parasuraman et al. (1988) are relevant in measuring life insurance service quality in the Indian context and there are not major reliability problems except a few statements as pointed out earlier. The real problem was found to be in the factor structure. The factor analysis gave a very different factor structure as compared to the proposed factor structure. Most of the items did not merge according to the dimensions proposed by Parasuraman et al. (1988). The factor analysis results of gap and perception scores highlight three-factor solution where as expectation scores provides four-factor solution. Specifically, in perception scale, items loaded on the first factor (F1) are mainly composed of those related to the standard dimensions of assurance, empathy, responsiveness; second factor (F2) contains tangibles items along with one item of empathy; the items loaded on the third factor (F3) include two assurance and two reliability items of the SERVQUAL scale. Likewise, in gap scale, first factor (F1) is a composition of assurance, empathy, responsiveness; second factor (F2) highlights tangibles along with one empathy item; and third factor (F3) represents reliability items along with one assurance item.

Surprisingly, in perception and gap scale, some of the items merged in a single factor. This was more noticeable for the items pertaining to the assurance, reliability, responsiveness, and empathy dimensions. These dimensions also showed significant reliability problems in case of expectations scores. Therefore, the statements of these dimensions could be modified or dropped and then the scale could be re-evaluated for its reliability and dimensionality. Most research studies do not support the five-factor structure of SERVQUAL as proposed by Parsuraman et al. (1988) and administering expectations items is also considered unnecessary (Kettinger et al., 1994). The results, however, can be better interpreted as being an even stronger support for the SERVPERF (i.e. performance only) approach as the "expectation portion of the SERVQUAL scale adds no additional information beyond that which is obtained from performance perceptions alone" (Brady et al., 2002). Finally, performance only (P) scale as suggested by Cronin and Taylor (1992) performs better than gap (P-E) scale of Parasuraman et al. (1988) in terms of reliability, explained variance, and its factor structure.

Overall, the results do indicate that a meaningful pattern or a higher level of abstraction can be obtained from SERVQUAL in the new context, although the original five dimension of the scale are not confirmed. However, SERVQUAL would need to be customized for each industry. Ladhari (2008) has also concluded in his study that the number and nature of the dimensions varied, depending on the service context; indeed, they varied even within the same service industry. Moreover, one has to bear in mind that the notion of service quality is industry and country specific (Ford et al., 1993; Akviran, 1994) because, a business person staying in a given hotel has different service criteria from those of a tourist (Eccles and Durrand, 1997). Furthermore, the factor structure for the lodging industry in Australia (Wilkins et al., 2007) was somewhat different from that in North America (Knutson et al., 1990; Saleh and Ryan, 1991; Getty and Getty, 2003). Moreover, the factor structure varied within a given country. For example, the factor structure for the lodging industry in North America varied from five-factor (Knutson et al., 1990; Getty and Getty, 2003) to four-factor (Saleh and Ryan, 1991). In addition, Zhao et al. (2002) noted that SERVQUAL five-factor structure do not match with the factors obtained through factor analysis in the Chinese retail sector and also concluded that this may be in part due to cultural difference between china and Western countries. Hence, it is apparent in the present study that the criteria used to evaluate service quality and the number of dimensions can be varied according to the country specific characteristics like that of Indian life insurance industry. Further, as per the views of Siddiqui et al. (2010), for service quality modeling, a set of dimensions is required, but there seems to be no universal dimension; it needs to be modified as per the service in consideration. Thus, SERVQUAL dimensions require re-examination in the context of Indian life insurance sector. Hence, it would be advisable to re-define the factors according to the results 
obtained under the Indian conditions and then carry out the gap analysis for accurate responses from the customers and also for more relevant suggestions for improvements.

\subsection{Managerial Implication}

In the critical moments of truth, only those organizations which will be in position to enhance quality in their end products will sustain and maintain their position (Brown et al., 2005). Therefore, LIC must have to focus on quality improvement strategy to remove the quality flaws by giving the first priority to the items with biggest gaps and subsequently to the items with lowest gaps. However, SERVQUAL instrument is moving around the human element of service delivery (which consists of assurance, reliability, responsiveness \& empathy) and tangibles attributes (Sureshchandar et al., 2001), so, LIC should ensure that agents \& employees are well trained and understand the needs of customers and provide services accordingly that the organization is supposed to provide for its customers. Besides, in a competitive environment, by performing on differential strategies aimed at improving the service quality, LIC will be able to add value to their relationship with the current and prospective customers.

\section{Limitations and Further Research}

The conclusion drawn from the results of this study should be viewed under the following limitations. Firstly, this study was carried out mainly in Punjab; therefore, the results obtained may not be pertinent to the country as a whole. Of course, the study can be extended to other states of India. Secondly, the study has been steered with non-probability convenience sampling in a single public life insurance company as the sampling method. To achieve higher statistical sophistication, the study can be steered with a probability sampling method. Thirdly, the present study has been conducted by taking a sample of 337 customers of LIC (a public company), ignoring the private life insurance companies. This cannot lead to the generalizability of the findings and the results may not be implied conclusively to the whole life insurance industry. Additional studies are recommended to fill this gap. Fourthly, in the current study, exploratory factor analysis using principal component method with varimax rotation has been used. Moreover, confirmatory factor analysis technique could be used to confirm the right dimension structure for life insurance sector. Finally, this study has concentrated on SERVQUAL - 22 items scale (five-factor structure) as developed by Parasuraman et al. $(1985,1988)$. Hence, critical factors as proposed by Sureshchandar et al. (2001) to measure service quality might also be studied in the future. These limitations may decrease the ability of generalizing the results of this study to other life insurance companies' settings. Therefore, the conceptual and methodology limitations of this study need to be considered when designing future research.

\section{Conclusion}

Indeed, factors obtained through exploratory factor analysis (as shown in Table 3,4,5) did not follow the factor structure as given by Parasuraman et al. (1988). The gap scores did not merge into five dimensions of service quality, however, the perceptions scores merged into three dimensions. Nevertheless, the bulk of empirical evidence in the literature rejects the five-factor structure and questions the SERVQUAL application to wide variety of services (Gupta, 2005). Many studies (e.g. Babakus and Boller, 1992; Carman, 1990) have illustrated that the number of service quality dimensions are dependent upon the particular service being offered. Furthermore, SERVQUAL metric requires substantial modification (customization) prior to its application. Researchers ought to be cautious when applying the diagnostic; SERVQUAL is not a ready to use tool-kit: although robust, the metric calls for customization (Evangelos et al., 2004). Consequently, the findings of the present study indicate that SERVQUAL instrument is not applicable to the Indian life insurance sector; therefore, further research is imperative to understand and improve life insurance service quality in India. Few statements which showed reliability problems should be restated or substituted by more relevant statements and a separate instrument may also be developed to measure service quality for the life insurance industry. Although, SERVQUAL dimensions cover only human element of service delivery and tangibles facet of the service, the concept of service quality does not confine to the realms of these factors, but also encompasses other critical factors namely, service product or the core service, systematization of the service delivery, and social responsibility (Sureshchandar et al., 2001). Therefore, in future these critical factors might also be considered to measure service quality in the life insurance industry.

Results of averages computed on gap scores indicate negative gaps in all items of service quality which revealed that expectations of customers were more than their perceptions. The negative gaps indicate that the service quality level was unsatisfactory. Accordingly, maximum gap was found in respect of tangibles items followed by responsiveness, assurance, empathy, and reliability items. The greatest negative scores have made it necessary for LIC to take corrective measures and focus on quality improvement to increase its effectiveness and to compete successfully in the life insurance industry. For that reason, quality improvement strategy should be opted in the order of the highest to the lowest gaps. Conversely, failing to make improvement will widen the gaps and which will result in customer dissatisfaction towards service quality of LIC.

Overall, this study also found that the gap (P-E) model as proposed by Parasuraman et al. (1988) did not perform as well as the perception based performance (P) model of Cronin and Taylor (1992) in terms of reliability, explained variance and its factor structure. In addition, suggested improvements in the service quality are required to be focused 
by LIC to retain potential customers, gain a competitive advantage, increase its market share \& profitability, and to ensure its sustainability especially in the developing countries like India. Moreover, the continuous examination of customers' perceptions and expectations is needed in order to know about what actually the customers want, in that way, up-to-date measures are needed to be employed, basing them on the customers' stated needs and demands to improve the service quality.

\section{References}

Akviran, N.K. (1994). Developing an instrument to measure customer service quality in branch banking. International Journal of Bank Marketing, 12 (6), pp. 10-18. http://dx.doi.org/10.1108/02652329410063223

Arasli, H., Mehtap-Smadi, S., \& Katircioglu, S.T. (2005). Customer service quality in the greek cypriot banking industry. Managing Service Quality, 15 (1), pp. 41-56. http://dx.doi.org/10.1108/09604520510575254

Asubonteng, P., McCleary, K.J., \& Swan, J.E. (1996). SERVQUAL revisited: a critical review of service quality. Journal of Services Marketing, 10 (6), pp. 62-81. http://dx.doi.org/10.1108/08876049610148602

Babakus, E., \& Boller, G.W. (1992). An empirical assessment of the SERVQUAL scale. Journal of Business Research, 24 ( 3 ), pp. 253-268. http://dx.doi.org/10.1016/0148-2963(92)90022-4

Babakus, E., Pedrick, D.L., \& Inhofe, M. (1993). Empirical examination of a direct measure of perceived service quality using SERVQUAL items. Unpublished manuscript, Memphis State University, TN.

Berry, L.L., Parasuraman, A., \& Zeithaml, V.A. (1985). The service quality puzzle. Business Horizon, 31(5), pp. 3543. http://dx.doi.org/10.1016/0007-6813(88)90053-5

Bowers, M.R., Swan, J.E., \& Koehler, W.F. (1994). What attributes determine quality and satisfaction with health care delivery?. Health Care Management Review, 19(4), pp. 49-55.

Brady, M.K., Cronin, J.J., \& Brand, R.R. (2002). Performance-only measures of service quality: a replication and extension. Journal of Business Research, 55(1), pp. 17-31.

Brown, S., Lamming, R., Bessant, J., \& Jones, P. (2005). Strategic Operations Management (2nd Edition). Burlington: Elsevier Butterworth-Heinemann.

Brown, T.J., Churchill Jr., G.A., \& Peter, J.P. (1993). Research note: Improving the measurement of service quality. Journal of Retailing, 69 (1), pp. 127-139. http://dx.doi.org/10.1016/S0022-4359(05)80006-5

Buttle, F. (1996). SERVQUAL: review, critique, research agenda. European Journal of Marketing, 30 (1), pp. 8-25. http://dx.doi.org/10.1108/03090569610105762

Carman, J.M. (1990). Consumer perceptions of service quality: an assessment of the SERVQUAL dimensions. Journal of Retailing, 66 (1), pp. 33-55.

Carr, C.L. (2002). Measuring information system service quality: SERVQUAL from the other side. MIS Quarterly, 26 (2), pp. 145-66. http://dx.doi.org/10.2307/4132324

Cook, C., Heath, F., \& Thompson, B. (2002). Score norms for improving library service quality: a LibQUAL+ study. Portal: Libraries and the Academy, 2, pp. 13-26. http://dx.doi.org/10.1353/pla.2002.0007

Cronin, J.J., \& Taylor, S.A. (1994). SERVPERF versus SERVQUAL, reconciling performance-based and perceptions-minus-expectations measurement of service quality. Journal of Marketing, 58 (January), pp.125-131. http://dx.doi.org/10.2307/1252256

Cronin, J.J. Jr., \& Taylor, S.A. (1992). Measuring Service Quality: A Reexamination and Extension. Journal of Marketing, 56(3), pp. 55-68. http://dx.doi.org/10.2307/1252296

Crosby, P.B. (1979). Quality is free: the art of making quality certain. Americal Library, New York, NY

Donnelly, M., Wisniewski, M., Dalrymple, J.F., \& Curry, A.C. (1995). Measuring service quality in local government the SERVQUAL approach. International Journal of Public Sector Management, 8 (7), pp. 14-19. http://dx.doi.org/10.1108/09513559510103157

Dotchin, J.A., \& Oakland, J.S. (1994). Total quality management in services Part 1: understanding and classifying services. International Journal of Quality \& Reliability Management, 11(3), pp. 9-26. http://dx.doi.org/10.1108/02656719410056459

Eccles, G., \& Durrand, P. (1997). Improving service quality: lessons and practice from the hotel sector. Managing Service Quality, 7 (5), pp. 224-260. http://dx.doi.org/10.1108/09604529710172845

Ekinci, Y., Prokopaki, P., \& Cobanoglu, C. (2003). Service quality in Cretan accommodations: marketing strategies for the UK holiday market. International Journal of Hospitality Management, 22 (1), pp. 47-66. http://dx.doi.org/10.1016/S0278-4319(02)00072-5 
Espinoza, M.M. (1999). Assessing the cross-cultural applicability of a service quality measure: a comparative study between Quebec and Peru. International Journal of Service Industry Management, 10 (5), pp. 449-468. http://dx.doi.org/10.1108/09564239910288987

Evangelos, T., Simmy, M., \& Graham, R.K. (2004). Quality improvement in the Greek and Kenyan insurance industries. Archives of Economic History, 16 (2), pp. 93-116, Available: http://www.lums.lancs.ac.uk/publications/viewpdf/000297/.

Finn, D.W., \& Lamb, C.W. (1991). An evaluation of the SERVQUAL scale in a retailing setting, in Holman, R and Solomon, M R (eds.), Advances in Consumer Research, Provo, UT: Association for Consumer Research, pp. 480-930.

Fisk, R.P., Brown, S.W., \& Bitner, M.J. (1993). Tracking the evolution of the services marketing literature. Journal of Retailing, 69 (1), pp. 61- 103. http://dx.doi.org/10.1016/S0022-4359(05)80004-1

Ford, J.W. Joseph, M., \& Joseph, B. (1993). Service quality in higher education: a comparison of universities in the United States and New Zealand using SERVQUAL. Unpublished manuscript, Old Dominion University, Norfolk, VA.

Freeman, K.D., \& Dart, J. (1993). Measuring the perceived quality of professional business services. Journal of Professional Services Marketing, 9 (1), pp. 27-47. http://dx.doi.org/10.1300/J090v09n01_04

Furrer, O., Liu, B.S.C., \& Sudharshan, D. (2000). The relationships between culture and service quality perceptions: basis for cross-cultural market segmentation and resource allocation. Journal of Service Research, 2 (4), pp. 355-370. http://dx.doi.org/10.1177/109467050024004

Frochot, I.V., \& Hughes, H. (2000). HISTOQUAL: an adaptation of SERVQUAL to historic houses. Tourism Management, 21 (2), pp. 157-167. http://dx.doi.org/10.1016/S0261-5177(99)00045-X

Gabbie, O., \& Neill, M.A. (1996). SERVQUAL and Northern Ireland hotel sector, a comparative analysis - part 1. Managing Service Quality, 8 (5), pp. 306-311.

Gagliano, K.B., \& Hathcote, J. (1994). Customer expectations and perceptions of service quality in apparel retailing. Journal of Services Marketing, 8 (1), pp. 60-69. http://dx.doi.org/10.1108/08876049410053311

Gayathri, H., Vinaya, M.C., \& Lakshmisha, K. (2005). A pilot study on the service quality of insurance companies. Journal of Services Research, 5 (2), pp. 123-38.

Getty, J.M., \& Getty, R.L. (2003). Lodging quality index (LQI): assessing customers perceptions of quality deliver. International Journal of Contemporary Hospitality Management, 15 (2), pp. 94-104. http://dx.doi.org/10.1108/09596110310462940

Gravin, D.A. (1983). Quality on the Line. Harvard Business Review, 61 (September-October), pp. 65-73.

Goswami, P. (2007). Customer satisfaction with service quality in the life insurance industry in India. ICFAI Journal of Services Marketing, 5 (1), pp. 25-30.

Gupta, G. (2005). Service quality: its measurement and relationship with other constructs. Synergy: I.T.S. Journal of I.T. and Management, 3 (1), pp. 41-48.

Hair, J.F., Black, W.C., Babin, B.J., \& Anderson, R.E. (2010). Multivariate Data Analysis (7th edition). Prentice Hall, Upper Saddle River, New Jersey.

Headley, D.E., \& Miller, S.J. (1993). Measuring service quality and its relationship to future consumer behavior. Journal of Health Care Marketing, 13 (4), pp. 32-41.

Jain, S.K., \& Gupta, G. (2004). Measuring service quality, SERVQUAL vs. SERVPERF scales. Vikalpa, 29 (2), pp. 25-37.

Jiang, J.J., Klein, G., \& Carr, C.L. (2002). Measuring information system service quality: SERVQUAL from the other side. MIS Quarterly, 24 (2), pp. 145-166. http://dx.doi.org/10.2307/4132324

Kara, A., S. Lonial, M. Tarım, \& S. Zaim (2005). A paradox of service quality in turkey the seemingly contradictory relative importance of tangible and intangible determinants of service quality. European Business Review, 17 (1), pp. 5-20. http://dx.doi.org/10.1108/09555340510576230

Karatepe, O.M., \& Avci, T. (2002). Measuring service quality in the hotel industry: evidence from Northern Cyprus. Anatolia: An International Journal of Tourism and Hospitality Research, 13 (1), pp. 19-32.

Kettinger, W.J., Lee, C.C., \& Lee, S. (1994). Global measures of information service quality: a cross-national study. Decision Sciences, 26 (5), pp. 569-588. http://dx.doi.org/10.1111/j.1540-5915.1995.tb01441.x

Khan, M. (2003). ECOSERV: ecotourists quality expectations. Annals of Tourism Research, 30 (1), pp. 109-124. http://dx.doi.org/10.1016/S0160-7383(02)00032-4 
Kilbourne, W.E., Duffy, J.A., Duffy, M., \& Giarchi, G. (2004). The applicability of SERVQUAL in cross-national measurements of health-care quality. Journal of Services Marketing, 18 (6/7), pp. 524-533. http://dx.doi.org/10.1108/08876040410561857

Knutson, B., Stevens, P., Wullaert, C., \& Yokoyoma, F. (1990). LODGSERV, a service quality index for the lodging industry. Hospitality Research Journal, 14 (2), pp. 227-284.

Kouthouris, C., \& Alexandris, K. (2005). Can service quality predict customer satisfaction and behavioral intention in the sport tourism industry? An application of the SERVQUAL model in an outdoors setting. Journal of Sport Tourism, 10 (2), pp. 101-111. http://dx.doi.org/10.1080/14775080500223165

Levy, M., \& Weitz, B. (2005). Retailing Management (6th Edition). Burr Ridge, IL: McGraw-Hill.

Ladhari, R. (2008). Alternative measure of service quality: a review. Journal of Managing Service Quality, 18 (1), pp. 65-86. http://dx.doi.org/10.1108/09604520810842849

Lam, S.S.K. (1997). SERVQUAL: a tool for measuring patients opinions of hospital service quality in Hong Kong. Total Quality Management, 8 (4), pp. 145-152. http://dx.doi.org/10.1080/0954412979587

Lam, T., \& Zhang, H.Q. (1999). Service quality of travel agents: the case of travel agents in Hon Kong. Tourism Management, 20 (3), pp. 341-349. http://dx.doi.org/10.1016/S0261-5177(98)00118-6

Lam, T.K.P. (2002). Making sense of SERVQUAL's dimensions to the Chinese customers in Macau. Journal of Market-focused Management, 5 (10), pp. 43-58. http://dx.doi.org/10.1023/A:1012575412058

Leste, M.R., \& Wanderley, V. (1997). The interactive approach to service quality and management. Deuxième Congres International Franco-Quebecois de Génie Industriel, ALBI 1997.

Malhotra, N.K (2007). Marketing research: an application orientation (5th Edition). Pearson Prentice Hall, New Delhi.

Mattson, J. (1994). Improving service quality in person-to-person encounters. The Service Industries Journal, 14 (1), pp. 45-61. http://dx.doi.org/10.1080/02642069400000004

Mehta, S.C., \& Durvasula, S. (1998). Relationship between SERVQUAL dimensions and organizational performance in the case of a business-to-business service. Journal of Business and Industrial Marketing, 13 (1), pp. 40-53. http://dx.doi.org/10.1108/08858629810206232

Mehta, S.C., Lobo, A., \& Khong, H.S. (2002). MSS, MSA and zone of tolerance as measures of service quality: a study in the life insurance industry. Second International Services Marketing Conference, University of Queensland, July 4-5, Available: http://maritimebusiness.amc.edu.au/.

Mei, A. W. O., Dean, A. M., \& White, C. J. (1999). Analysing service quality in the hospitality industry. Managing Service Quality, 9 (2), 136-143. http://dx.doi.org/10.1108/09604529910257920

Mey, L.P., Akbar, A.K., \& Fie, D.Y.G. (2006). Measuring service quality and customer satisfaction of the hotels in Malaysia: Malaysian, Asian and non-Asian hotel guests. Journal of Hospitality and Tourism Management, 13 (2), pp. 144-160. http://dx.doi.org/10.1375/jhtm.13.2.144

Nadiri, H., \& Hussain, K. (2005). Diagnosing the zone of tolerance for hotel services. Managing Service Quality, 15 (3), pp. 259-277. http://dx.doi.org/10.1108/09604520510597818

Naik, C.N. Krishna, Gantasala S.B., \& Gantasala, V.P. (2010). Service quality (SERVQUAL) and its effect on customer satisfaction in retailing. European Journal of Social Sciences, 16 (2), pp. 231-243.

Nunnally, J.C., \& Bernstein, I. (1994). Psychometric Theory, McGraw-Hill, New York.

Ovretveit, J. (1993). Measuring Service Quality. Hertfordshire, England: Technical Communication (Publishing) Ltd Ozer, L.S. (1999). Musteri tatmini ve tatmin teorilerine yonelik literaturedeki kuramsal tartismalar. Working paper, Ankara: Hacetepe University.

Parasuraman, A., Zeithaml V., \& Malhotra A. (2005). E-S-QUAL: a multiple-item scale for assessing electronic service quality. Journal of Service Research, 7 (3), pp. 213-233. http://dx.doi.org/10.1177/1094670504271156

Parasuraman, A., Zeithaml, V.A., \& Berry, L.L. (1985). A conceptual model of service quality and its implications for future research. Journal of Marketing, 49 (4), pp. 41-50. http://dx.doi.org/10.2307/1251430

Parasuraman, A., Zeithaml, V.A., \& Berry, L.L. (1988). SERVQUAL: a multiple item scale for measuring consumer perceptions of service quality, Journal of Retailing, 64 (1), pp. 12-37.

Parasuraman, A., Zeithaml, V.A., \& Berry, L.L. (1991b). Refinement and reassessment of the SERVQUAL scale. Journal of Retailing, 67 (4), pp. 420-450.

Parasuraman, A., Berry, L.L., \& Zeithaml, V.A. (1991a). Understanding, measuring and improving service quality findings from a multiphase research program. in: S.W. Brown, E. Gummesson, B. Edvardsson and B. Gustavsson (Eds), Service Quality: Multidisciplinary and Multinational Perspectives (Lexington Books, NY). 
Parasuraman, A., Zeithaml, V.A., \& Berry, L.L. (1993). Research note-more on improving service quality measurement. Journal of Retailing, 69 (1), pp. 140-147. http://dx.doi.org/10.1016/S0022-4359(05)80007-7

Parikh, D. (2006). Measuring retail service quality: an empirical assessment of the instrument. Vikalpa, 31 (2), pp. 45-55.

Pariseau, S.E., \& McDaniel, J.R. (1997). Assessing service quality in schools of business. International Journal of Quality and Reliability Management, 14 (3), pp. 204-218. http://dx.doi.org/10.1108/02656719710165455

Petrick, J.F. (2002). Development of a multi-dimensional scale for measuring the perceived value of a service. Journal of Leisure Research, 34 (2), pp. 119-134.

Qualls, William J., \& Rosa, JoseAntonio (1995). Assessing industrial buyers' perception of quality and their effects on satisfaction. Industrial Marketing Management, $24 \quad$ (5), $\quad$ pp. $\quad 359-369$. http://dx.doi.org/10.1016/0019-8501(95)00027-8

Rahtz, Don R., Sirgy, Joseph M., \& Kosenko, R. (1988). Using demographics and psychographic dimensions to discriminate between mature heavy and light television users: an exploratory analysis. Developments in Marketing Science, 11, pp. 2-7.

Rathmell, J.M. (1966). What is meant by services? Journal of Marketing, 30 (October), pp. 32-36.

Robinson, S., \& Pidd, M. (1998). Provider and customer expectations of successful simulation projects. Journal of the Operational Research Society, 49 (3), pp. 200-209. http://dx.doi.org/10.2307/1249496

Ryan, C., \& Cliff A. (1996). Users and non-users on the expectation item of the SERVQUAL scale. Annals of Tourism Research, 23 (4), pp. 931-934. http://dx.doi.org/10.1016/0160-7383(95)00096-8

Saleh, F., \& Ryan, C. (1992). Analysing service quality in the hospitality industry using the SERVQUAL model. Services Industries Journal, 11(3), pp. 324-343. http://dx.doi.org/10.1080/02642069100000049

Shemwell, D.J., Yavas, U., \& Bilgin, Z. (1998). Customer-service provider relationships: an empirical test of a model of service quality, satisfaction and relationship oriented. International Journal of Service Industry Management, 9 (2), pp. 155-168. http://dx.doi.org/10.1108/09564239810210505

Sherden, W. (1987). The erosion of service quality. Best's Review, 88 (5), pp. 22.

Siddiqui, Masood H., \& Sharma, T.G. (2010). Measuring the customer perceived service quality for life insurance services: an empirical investigation. International Business Research, 3 (3), pp. 171-186, Available: www.ccsenet.org/ibr.

Silvestro, R., Johnston, R., Fitzgerald, L., \& Voss, Ch. (1990). Quality measurement in service industry. International Journal of Service Industries Management, 1 (2), pp. 54-66. http://dx.doi.org/10.1108/EUM0000000002803

Sinclair, D., \& Zairi, M. (1995). Effective process management through performance measurement: part III-an integrated model of total quality-based performance measurement. Business Process Re-engineering and Management Journal, 1 (3), pp. 50-65. http://dx.doi.org/10.1108/14637159510103220

Spreng, R., \& Singh, A. (1993). Analysing service quality in the hospitality industry using the SERVQUAL model. Service Industries Journal, 1 (July), pp. 324-343.

Stafford, M.R., Stafford, T.F. and Wells, B.P. (1998). Determinants of service quality and satisfaction in the auto casualty claims process. Journal of Services Marketing, 12 (60), pp. 426-440. http://dx.doi.org/10.1108/08876049810242687

Stevens, P., Knutson, B., \& Patton, M. (1995). DINESERV: a tool for measuring service quality in restaurants. Cornell Hotel and Restaurant Administration Quarterly, 36 (2), pp. 56-60. http://dx.doi.org/10.1177/001088049503600226

Sureshchandar, G.S., Rajesndran, C., \& Kamalanabhan, T.J. (2001). Customer perceptions of service quality: a critique. Total Quality Management, 12 (1), pp. 111-124. http://dx.doi.org/10.1080/09544120020010138

Tsai, W.C., \& Huang, Y.M. (2002). Mechanisms linking employee affective delivery and customer behavioral intentions. Journal of Applied Psychology, 87(5), pp.1001-1008.

Teas, R.K. (1993). Expectations, performance evaluation, and consumers' perceptions of quality. Journal of Marketing, 57 (October), pp.18-34. http://dx.doi.org/10.2307/1252216

Timmers, G.J., \& Van Der Wiele, T. (1990). Airline quality: translating strategy into perception at 30,000 feet and 400 miles/hour, Paper presented at Quality in Services (QUIS-2), St John's University, USA.

Toncar, M.F., Reid, J.S., Burns, D.J., Anderson, C.E., \& Nguyen, H.P. (2006). Uniform assessment of the benefits of service learning, the development, evaluation, and implementation of the SELEB scale. Journal of Marketing Theory and Practice, 14 (3), pp. 223-238. http://dx.doi.org/10.2753/MTP1069-6679140304

Voss, C.A., Roth, A.V., Rosenzweig, E.D., Blackmon, K., \& Chase, R.B. (2004). A tale of two countries' conservatism, service quality, and feedback on customer satisfaction. Journal of Service Research, 6 (3), pp. 212-230. http://dx.doi.org/10.1177/1094670503260120 
Van Der Wal, R.W.E., Pampallis, A., \& Bond, C. (2002). Service quality in a cellular telecommunications company: a South African experience. Managing Service Quality, 12 (5), pp. 323-335. http://dx.doi.org/10.1108/09604520210442119

Wang, Y., Lo, H.P., \& Yang, Y. (2004). An integrated framework for service quality, customer value, satisfaction: evidence from china's telecommunication industry. Information Systems Frontiers, 6 (4), pp. 325-340. http://dx.doi.org/10.1023/B:ISFI.0000046375.72726.67

Westbrook, K.W., \& Peterson, R.M. (1998). Business-to-business selling determinants of quality. Industrial Marketing Management, 27 (1), pp. 51-62. http://dx.doi.org/10.1016/S0019-8501(97)00037-0

Wilkins, H., Merrilees, B., \& Herington, C. (2007). Toward an understanding of total service quality in hotels. International Journal of Hospitality Management, 26 (4), pp. 840-853. http://dx.doi.org/10.1016/j.ijhm.2006.07.006

Yang, C.C. (2003). Establishment and applications of the integrated model of service quality measurement. Managing Service Quality, 13 (4), pp. 310-324. http://dx.doi.org/10.1108/09604520310484725

Yoo, B., \& Donthu, N. (2001). Developing a scale to measure the perceived quality of internet shopping sites (SITEQUAL). Quarterly Journal of Electronic Commerce, 2 (1), pp. 31-47.

Zeithaml, V. (2000). Service quality, profitability and the economic worth of customers: what we know and what we need to learn. Journal of the Academy of Marketing Science, 28 (1), pp. 67-85. http://dx.doi.org/10.1177/0092070300281007

Zhao, X., Bai, C., \& Hui, Y.V. (2002). An empirical assessment and application of SERVQUAL in a mainland Chinese department store. Total Quality Management, 13 (2), pp. 241-254. http://dx.doi.org/10.1080/09544120120102478

Zhou, L., Zhang, Ye, \& Xu, Jia (2002). A critical assessment of SERVQUAL's applicability in the banking context of China. in Asia Pacific Advances in Consumer Research Volume 5, eds. Ramizwick and Tu Ping, Valdosta, GA : Association for Consumer Research, Pages: 14-21.

LIC, Re: India calling. [Online] Available: http://www.licindia.in/pages/Letter_NRI.pdf

Table 1. Demographic Characteristics of Sampled Customers ( $\mathrm{n}=337)$

\begin{tabular}{|c|c|c|c|}
\hline Demographics & No. of Customers (\%) & Demographics & No. of Customers (\%) \\
\hline $\begin{array}{l}\text { Gender } \\
\text { Male } \\
\text { Female }\end{array}$ & $\begin{array}{c}243(72.1) \\
94(27.9)\end{array}$ & $\begin{array}{l}\text { Educational Qualification } \\
\text { Matric } \\
\text { Senior secondary } \\
\text { Graduate } \\
\text { Post graduate } \\
\text { Professional } \\
\text { Any other }\end{array}$ & $\begin{array}{c}4(1.2) \\
22(6.5) \\
134(39.8) \\
109(32.3) \\
65(19.3) \\
3(0.9)\end{array}$ \\
\hline $\begin{array}{l}\text { Age } \\
\text { Upto } 20 \\
21-40 \\
41-60 \\
\text { Above } 60\end{array}$ & $\begin{array}{c}4(1.2) \\
193(57.3) \\
130(38.6) \\
10(3)\end{array}$ & $\begin{array}{l}\text { Occupation } \\
\text { Serviceman } \\
\text { Businessman/self-employed } \\
\text { Professional } \\
\text { Any other } \\
\end{array}$ & $\begin{array}{c}145(43.0) \\
115(34.1) \\
65(19.3) \\
12(3.6) \\
\end{array}$ \\
\hline $\begin{array}{l}\text { Marital Status } \\
\text { Married } \\
\text { Unmarried }\end{array}$ & $\begin{array}{c}278(82.5) \\
59(17.5)\end{array}$ & $\begin{array}{l}\text { Monthly Income (Rs.) } \\
\text { Up to } 15000 \\
15001-30000 \\
30001-45000 \\
\text { Above } 45000 \\
\end{array}$ & $\begin{array}{c}61(18.1) \\
156(46.3) \\
67(19.9) \\
53(15.7)\end{array}$ \\
\hline $\begin{array}{l}\text { Place of Residence } \\
\text { Rural } \\
\text { Urban }\end{array}$ & $\begin{array}{c}19(5.6) \\
318(94.4)\end{array}$ & $\begin{array}{l}\text { Total Number of Policies } \text { Bought } \\
\text { (Individually) } \\
\text { One } \\
\text { Two } \\
\text { More than two } \\
\end{array}$ & $\begin{array}{l}137(40.7) \\
97(28.8) \\
103(30.6)\end{array}$ \\
\hline $\begin{array}{l}\text { City } \\
\text { Amritsar } \\
\text { Jalandhar } \\
\text { Ludhiana }\end{array}$ & $\begin{array}{c}146(43.3) \\
114(33.8) \\
77(22.9)\end{array}$ & $\begin{array}{l}\text { Mode of Payment } \\
\text { Monthly } \\
\text { Quarterly } \\
\text { Half-yearly } \\
\text { Yearly } \\
\text { More than two mode }\end{array}$ & $\begin{array}{c}24(7.1) \\
59(17.5) \\
78(23.1) \\
156(46.3) \\
20(5.9)\end{array}$ \\
\hline
\end{tabular}

Note: Figures in parentheses show percentages. 
Table 2. Reliability Coefficients (alpha) of SERVQUAL Scale for Customers ( $\mathrm{n}=337$ )

\begin{tabular}{|l|c|c|c|c|}
\hline \multicolumn{1}{|c|}{ Dimensions } & Total no. of items & Perception (P) & Expectations (E) & Gap \\
\hline Assurance (A1,A2,A3,A4)* & 04 & 0.7148 & 0.4548 & 0.6452 \\
\hline Reliability (RL1,RL2,RL3)* & 03 & 0.7390 & 0.2928 & 0.6655 \\
\hline Empathy (E1, E2, E3)* & 03 & 0.7084 & 0.5033 & 0.4905 \\
\hline Responsiveness (RS1,RS2, RS3)* & 03 & 0.8134 & 0.5252 & 0.7384 \\
\hline Tangible (T1,T2,T3)* & 03 & 0.8218 & 0.4208 & 0.6872 \\
\hline Overall (16 items) & & $\mathbf{0 . 9 1 1 0}$ & $\mathbf{0 . 7 8 4 2}$ & $\mathbf{0 . 8 7 0 1}$ \\
\hline
\end{tabular}

Note: *The symbols in parentheses indicate the questions included in the dimension. For example, A1, A2, A3 and A4 represent the first, second, third and fourth questions related to the Assurance dimension in the SERVQUAL instrument. The simplified questions are shown in Appendix I.

Table 3. Results of Factor Analysis of Perception (P) Scores by Customers (Extraction Method: Principal Component Analysis. Rotation Method: Varimax with Kaiser Normalization)

\begin{tabular}{|c|c|c|c|c|c|c|}
\hline Factor Label & Item No. & Total Items & Factor Loading & Eigen Value & Variance & Cronbach Alpha \\
\hline \multirow[t]{7}{*}{$\mathrm{F} 1$} & E2 & 08 & 0.815 & 6.639 & 44.262 & 0.9094 \\
\hline & E1 & & 0.787 & & & \\
\hline & $\mathrm{RS} 2$ & & 0.773 & & & \\
\hline & $\mathrm{A} 1$ & & 0.747 & & & \\
\hline & RS1 & & 0.745 & & & \\
\hline & $\mathrm{A} 2$ & & 0.728 & & & \\
\hline & RS3 & & 0.700 & & & \\
\hline \multirow[t]{4}{*}{$\mathrm{F} 2$} & $\mathrm{~T} 1$ & 04 & 0.821 & 1.757 & 11.711 & 0.8332 \\
\hline & $\mathrm{T} 3$ & & 0.799 & & & \\
\hline & $\mathrm{T} 2$ & & 0.770 & & & \\
\hline & E3 & & 0.717 & & & \\
\hline \multirow[t]{4}{*}{$\mathrm{F} 3$} & RL1 & 04 & 0.823 & 1.314 & 8.763 & 0.7473 \\
\hline & RL2 & & 0.738 & & & \\
\hline & A3 & & 0.632 & & & \\
\hline & A4 & & 0.520 & & & \\
\hline
\end{tabular}

Note: Factor loadings below 0.50 are not shown in this Table.

Table 4. Results of Factor Analysis of Expectations (E) Scores by Customers (Extraction Method: Principal Component Analysis. Rotation Method: Varimax with Kaiser Normalization)

\begin{tabular}{|c|c|c|c|c|c|c|}
\hline Factor Label & Item No. & Total Items & Factor Loading & Eigen Value & Variance & Cronbach Alpha \\
\hline F1 & E1 & 07 & 0.695 & 4.027 & 25.166 & 0.7569 \\
\hline & RL2 & & 0.640 & & & \\
\hline & A1 & & 0.629 & & & \\
\hline & E2 & & 0.605 & & & \\
\hline & RS1 & & 0.595 & & & \\
\hline & RS2 & & 0.549 & & & \\
\hline & A2 & & 0.507 & & & \\
\hline F2 & E3 & 02 & 0.845 & 1.765 & & 0.7136 \\
\hline & T1 & & 0.817 & & & \\
\hline F3 & A3 & 03 & 0.693 & 1.403 & & 0.766 \\
\hline \\
\hline
\end{tabular}

Note: Factor loadings below 0.50 are not shown in this Table. 
Table 5. Results of Factor Analysis of Gap (P-E) Scores by Customers (Extraction Method: Principal Component Analysis. Rotation Method: Varimax with Kaiser Normalization)

\begin{tabular}{|c|c|c|c|c|c|c|}
\hline Factor Label & Item No. & Total Items & Factor Loading & Eigen Value & Variance & Cronbach Alpha \\
\hline \multirow[t]{8}{*}{$\mathrm{F} 1$} & RS2 & 08 & 0.760 & 5.752 & 35.952 & 0.8696 \\
\hline & E1 & & 0.747 & & & \\
\hline & E2 & & 0.734 & & & \\
\hline & A1 & & 0.687 & & & \\
\hline & RS1 & & 0.684 & & & \\
\hline & $\mathrm{A} 2$ & & 0.668 & & & \\
\hline & RS3 & & 0.649 & & & \\
\hline & $\mathrm{A} 4$ & & 0.542 & & & \\
\hline \multirow[t]{4}{*}{$\mathrm{F} 2$} & $\mathrm{~T} 1$ & 04 & 0.784 & 1.762 & 11.015 & 0.6872 \\
\hline & $\mathrm{T} 2$ & & 0.726 & & & \\
\hline & $\mathrm{T} 3$ & & 0.675 & & & \\
\hline & E3 & & 0.660 & & & \\
\hline \multirow[t]{4}{*}{$\mathrm{F} 3$} & RL2 & 04 & 0.767 & 1.258 & 7.862 & 0.6864 \\
\hline & RL1 & & 0.660 & & & \\
\hline & A3 & & 0.649 & & & \\
\hline & RL3 & & 0.504 & & & \\
\hline
\end{tabular}

Note: Factor loadings below 0.50 are not shown in this Table.

Table 6. Gap between Perception and Expectations (P-E) for Customers $(n=337)$

\begin{tabular}{|c|c|c|}
\hline Sr. No. & Items/Statements & Gap Scale (WAS) \\
\hline 1 & $\begin{array}{l}\text { Agents and employees who have the proper knowledge and competence to answer customers' specific } \\
\text { queries and requests }\end{array}$ & -1.84 \\
\hline 2 & Agents and Employees who instill confidence in customers by proper behavior & -1.58 \\
\hline 3 & Making customers feel safe and secure in their transactions & -1.51 \\
\hline 4 & Appropriate behavior of the concerned staff & -1.87 \\
\hline 5 & Providing promised services as per the set schedule & -1.67 \\
\hline 6 & Providing services right the first time & -1.70 \\
\hline 7 & Showing sincere interest in solving customers' problems & -1.72 \\
\hline 8 & Giving caring and individual attention to customers by having customers' best interest $\mathrm{s}$ at heart & -1.83 \\
\hline 9 & Agents and Employees who understand the specific needs of their customers & -1.64 \\
\hline 10 & Having convenient operating hours and days of the branches for the customers & -1.72 \\
\hline 11 & Apprising the customers of the nature and schedule of services available in the organization & -1.66 \\
\hline 12 & Willingness to help customers and the readiness to respond to customers' requests & -1.92 \\
\hline 13 & Providing prompt service to customers & -1.62 \\
\hline 14 & Visually appealing materials and facilities associated with the service & -2.02 \\
\hline 15 & Staff appeared neat and professional & -2.15 \\
\hline 16 & Modern looking updated equipment, fixtures, and facilities & -1.97 \\
\hline
\end{tabular}


Appendix I: List of original SERVQUAL 22-items as proposed by Parasuraman et al. (1988) and modified 16 items used in the present study

\begin{tabular}{|c|c|c|c|}
\hline Dimensions & Items originally in SERVQUAL & Modified items in the present instrument & Item code \\
\hline \multirow[t]{4}{*}{ Assurance } & $\begin{array}{l}\text { Employees who have the knowledge to answer } \\
\text { customer questions }\end{array}$ & $\begin{array}{l}\text { Agents and employees have the proper } \\
\text { knowledge and competence to answer } \\
\text { customers' specific queries and requests }\end{array}$ & A1 \\
\hline & Employees who instill confidence in customers & $\begin{array}{l}\text { Agents and employees who instill confidence } \\
\text { in customers through proper behavior }\end{array}$ & A2 \\
\hline & Making customers feel safe in their transactions & $\begin{array}{l}\text { Making customers feel safe and secure in their } \\
\text { transactions }\end{array}$ & A3 \\
\hline & Employees who are consistently courteous & Appropriate behaviour of the concerned staff & A4 \\
\hline \multirow[t]{3}{*}{ Reliability } & $\begin{array}{l}\text { Providing services at the promised time } \\
\text { Providing services as promised }\end{array}$ & $\begin{array}{l}\text { Providing promised services as per the set } \\
\text { schedule }\end{array}$ & RL1 \\
\hline & Providing services right the first time & Providing services right the first time & RL2 \\
\hline & $\begin{array}{l}\text { Showing sincere interest in solving customer } \\
\text { problems }\end{array}$ & $\begin{array}{l}\text { Showing sincere interest in solving customers' } \\
\text { problems }\end{array}$ & RL3 \\
\hline \multirow[t]{3}{*}{ Empathy } & $\begin{array}{l}\text { Giving customers individual attention } \\
\text { b. Employees who deal with customers in a } \\
\text { caring fashion } \\
\text { c. Having the customers' best interest at heart }\end{array}$ & $\begin{array}{l}\text { Giving caring and individual attention to } \\
\text { customers by having customers' best interests } \\
\text { at heart }\end{array}$ & E1 \\
\hline & $\begin{array}{l}\text { Employees who understand the needs of their } \\
\text { customers }\end{array}$ & $\begin{array}{l}\text { Agents and employees who understand the } \\
\text { specific needs of their customers }\end{array}$ & E2 \\
\hline & $\begin{array}{l}\text { Having business hours convenient for their } \\
\text { customers }\end{array}$ & $\begin{array}{l}\text { Having convenient operating hours and days of } \\
\text { the branches for the customers }\end{array}$ & E3 \\
\hline \multirow[t]{3}{*}{ Responsiveness } & $\begin{array}{l}\text { Keeping customers informed about when } \\
\text { services will be performed }\end{array}$ & $\begin{array}{l}\text { Apprising the customers of the nature and } \\
\text { schedule of services available in the } \\
\text { organization }\end{array}$ & RS1 \\
\hline & $\begin{array}{l}\text { a. Willingness to help customers } \\
\text { b. Readiness to respond to customers' } \\
\text { requests }\end{array}$ & $\begin{array}{l}\text { Willingness to help customers and the } \\
\text { readiness to respond to customers' requests }\end{array}$ & RS2 \\
\hline & Providing prompt service to customers & Providing prompt service to customers & RS3 \\
\hline \multirow[t]{3}{*}{ Tangibles } & $\begin{array}{l}\text { a. Visually appealing facilities } \\
\text { b. Visually appealing materials } \\
\text { associated with the service }\end{array}$ & $\begin{array}{l}\text { Visually appealing materials and facilities } \\
\text { associated with the service }\end{array}$ & $\mathrm{T} 1$ \\
\hline & $\begin{array}{l}\text { Employees who have a neat and professional } \\
\text { appearance }\end{array}$ & Staff appeared neat and professional & $\mathrm{T} 2$ \\
\hline & Modern equipment & $\begin{array}{l}\text { Modern looking updated equipment, fixtures } \\
\text { and facilities }\end{array}$ & $\mathrm{T} 3$ \\
\hline
\end{tabular}

